Bull. Chem. Soc. Ethiop. 2012, 26(1), 103-113.

ISSN 1011-3924

Printed in Ethiopia

DOI: http://dx.doi.org/10.4314/bcse.v26i1.11

(c) 2012 Chemical Society of Ethiopia

\title{
SYNTHESIS OF 8-METHYLNONANE-1,6,7-TRIEN-4-ONE AND RELATED ALLENES AS POTENTIALLY USEFUL SYNTHETIC PRECURSORS
}

\author{
S.J.M. Mdachi ${ }^{*}$ \\ Department of Chemistry, University of Dar es Salaam P.O. Box 35061, Dar es Salaam, \\ Tanzania
}

(Received February 7, 2011; revised September 20, 2011)

\begin{abstract}
The allenic ketone 8-methylnonane-1,6,7-trien-4-one and related allenes have been synthesized from simple commercially available materials. Since allenes analogous to 8-methylnonane-1,6,7-trien-4-one have previously been transformed to substituted bicyclo[3.3.0]octanones via corresponding bicyclo[3.2.0]heptanones, it is anticipated that the present allenic ketone may also undergo similar transformations. Substituted bicyclo[3.3.0] octanones are known synthetic precursors of tricyclic sesquiterpenes. Thus, 8-methylnonane-1,6,7trien-4-one presents itself as a possible precursor for the synthesis of tricyclopentanoid ring system present in sesquiterpenes such as hirsutene and $\Delta^{9(12)}$-capnellene.
\end{abstract}

KEY WORDS: 8-Methylnonane-1,6,7-trien-4-one, Allenic ketone, Allenes, Ene-allenes

\section{INTRODUCTION}

Allenes comprise a class of compounds characterized by two cumulated double bonds [1]. One of the first synthesized allene is penta-2,3-dienedioic acid (1) (Figure 1). It was reported as early as in 1887 by Burton and Pechmann [2], but the structure was not confirmed until 1954 [3]. The unjustified belief that allenes would be unstable because of the cumulated system greatly hindered the development of allene chemistry. For this reason and the lack of methodology for their preparation in the first half of the 20th century, allenes were for a long time viewed as laboratory curiosities. Nowadays, the preparation of allenic hydrocarbons and variously functionalized allenes has been widely investigated and a good number of methods exist for obtaining a variety of allenes [4]. The unusual chemistry and applications of allenes as synthetic intermediates have also been extensively investigated and reviewed [5-8]. Of particular interest to us is the application of intramolecular $[2+2]$ cycloaddition of ene-allenes $[9,10]$ so as to assemble a functionalized bicyclo[3.3.0] octanone via a corresponding bicyclo[3.2.0]heptanone. We envisioned assembling an appropriately substituted bicyclo[3.3.0]octanone, which is capable of being transformed to the tricyclic sesquiterpene hirsutene (2) and/or $\Delta^{9(12)}$-capnellene (3) (Figure 1).

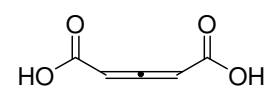

Penta-2,3-dienedioic acid (1)

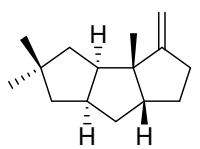

Hirsutene (2)

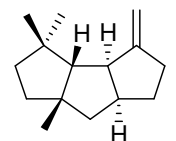

$\Delta^{9(12)}$-Capnellene (3)

Figure 1. Penta-2,3-dienedioic acid (1), tricyclic sesquiterpene hirsutene (2) and $\Delta^{9(12)}$ capnellene (3).

Retrosynthetic analyses of compounds $\mathbf{2}$ and $\mathbf{3}$ based on the aforementioned proposal should lead to 8-methylnonane-1,6,7-trien-4-one (4a) and 2,8-dimethylnonane-1,6,7-trien-4-one (4b) as depicted in Scheme 1.

*Corresponding author. E-mail: stephenmdachi@yahoo.com 

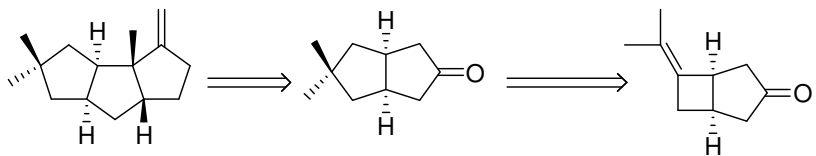

Hirsutene (2)

bicyclo[3.3.0]octanone $5 a$

bicyclo[3.2.0]heptanone (6a)

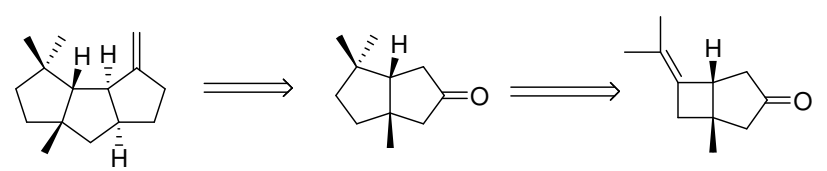

$\Delta^{9(12)}$-Capnellene (3) bicyclo[3.3.0]octanone 5b bicyclo[3.2.0]heptanone (6b)

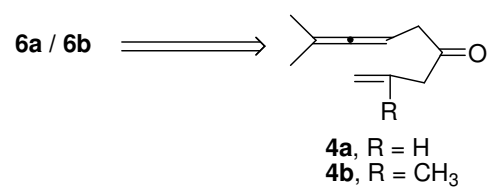

Scheme 1

It was anticipated that the [2+2] ene-allene cycloaddition of compound 4 should lead to the bicyclo[3.2.0]heptanone $\mathbf{6}$ and the acid catalysed rearrangement of $\mathbf{6}$ should furnish the bicyclo[3.3.0]octanone 5. The difference in the position of the gem-dimethyl substructure in compounds $\mathbf{5 a}$ and $\mathbf{5 b}$ can be mechanistically rationalized by the anticipated acid catalysed rearrangement of compound(s) 6 as depicted in Scheme 2.

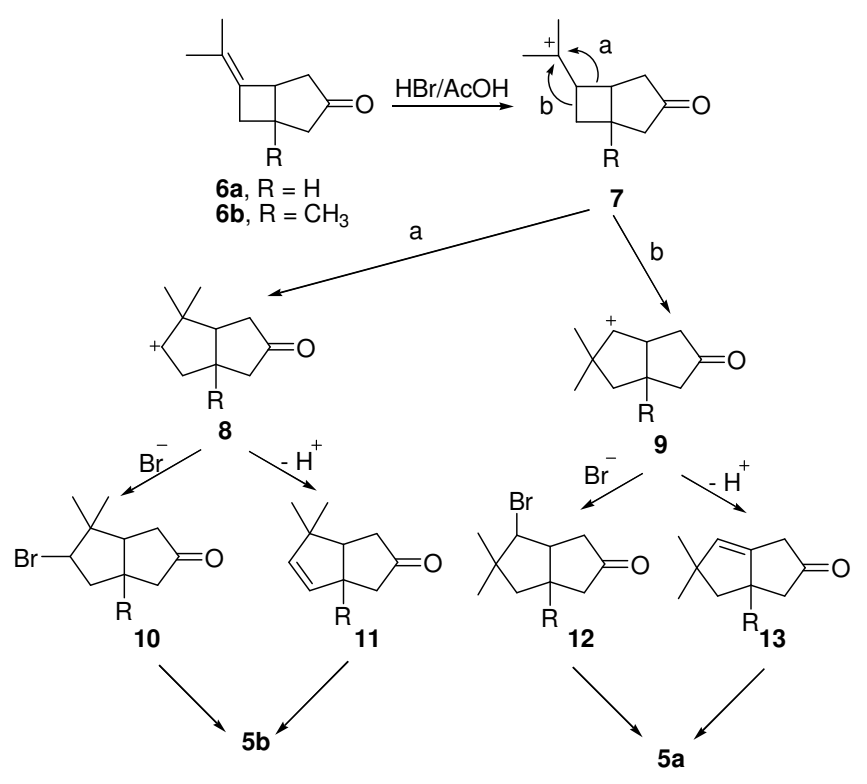

Scheme 2

Bull. Chem. Soc. Ethiop. 2012, 26(1) 
Protonation of 6 should lead to the carbocation 7, that can rearrange to 8 (path a) or to 9 (path b). Reactions with bromide ion or deprotonation of 8 and $\mathbf{9}$ should give compounds 10-13. Debromination of $\mathbf{1 0}$ and hydrogenation of $\mathbf{1 1}$ should afford the desired bicyclo[3.3.0]octanone 5b. Similarly, debromination of $\mathbf{1 2}$ and hydrogenation of $\mathbf{1 3}$ should lead to $\mathbf{5 a}$.

Precedence of the acid catalysed rearrangement was available from the previous observation [11] that the treatment of compound $\mathbf{1 4}$ with $\mathrm{HBr}$ led to a practically quantitative conversion to 15 (Scheme 3).

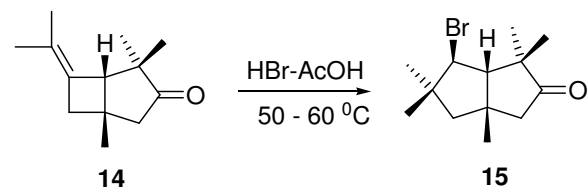

Scheme 3

In order to test our retrosynthesis (Scheme 1), our first task was to synthesize the allenic ketones $\mathbf{4 a}$ and $\mathbf{4 b}$. The present paper, therefore, focuses attention on synthetic work with 8 methylnonane-1,6,7-trien-4-one (4a) as the target.

\section{RESULTS AND DISCUSSION}

Initially we designed a synthetic strategy that aimed at 5-methyl-3,4-hexadienal (16) as a key intermediate towards the targeted allenic ketones $\mathbf{4 a}$ and $\mathbf{4 b}$. One obvious way to obtain compound 16 would be to oxidize its alcohol precursor, that is 5-methyl-3,4-hexadienol (17). Attempts were made to prepare the dienol 17 by first employing a Claisen type [3,3] sigmatropic rearrangement of the propargyl vinyl ether 18, which was generated in situ from 2-methyl-3butyn-2-ol, triethyl orthoacetate and propionic acid (Scheme 4), to give ethyl 5-methyl-3,4hexadienoate (19). On encountering a problem in the reduction of the $\beta$-allenic ester 19 to obtain the alcohol 16, a new route to the latter compound was conceived. In this case, 2-(2,2dibromo-3,3-dimethylcyclopropyl) ethanol (20) was envisioned as the immediate precursor to the allenic alcohol 17. Compound 20 was obtained in $84-87 \%$ yield from 21 through a BaeyerVilliger oxidation followed by a base catalysed hydrolysis of the resulting ester $\mathbf{2 2}$. The ketone 21 was prepared in $90 \%$ overall yield from the readily available 6-methyl-5-hepten-2-one in three simple steps, which are: protection of the carbonyl group as a cyclic ketal [12], addition of the dibromo carbene and deprotection of carbonyl group in that order. Therefore, the overall yield of alcohol 20 from 6-methyl-5-hepten-2-one was 76\%.

Having obtained compound $\mathbf{2 0}$ in good yield, the stage was set for the preparation of 5methyl-3,4-hexadienol (17), the immediate precursor for 16. The conversion of $\mathbf{2 0}$ to $\mathbf{1 7}$ was achieved in $95 \%$ yield by treatment of an ice-cooled ethereal solution of compound $\mathbf{2 0}$ with an ethereal solution of $1.5 \mathrm{M} \mathrm{MeLi}$ in an inert atmosphere. It is worth mentioning that 5-methyl3,4-hexadienol (17) was prepared in 76\% overall yield following a six steps procedure from 1,3propanediol [10]. The preparation reported in the present work afforded the dienol 17 in comparable yields $(72 \%)$ in six steps utilizing simple reagents. However, oxidation of the allenic alcohol 17 by the chromium trioxide-pyridine complex gave the isomerized aldehyde 5methyl-2,4-hexadienal (23) instead of the targeted aldehyde 16. 


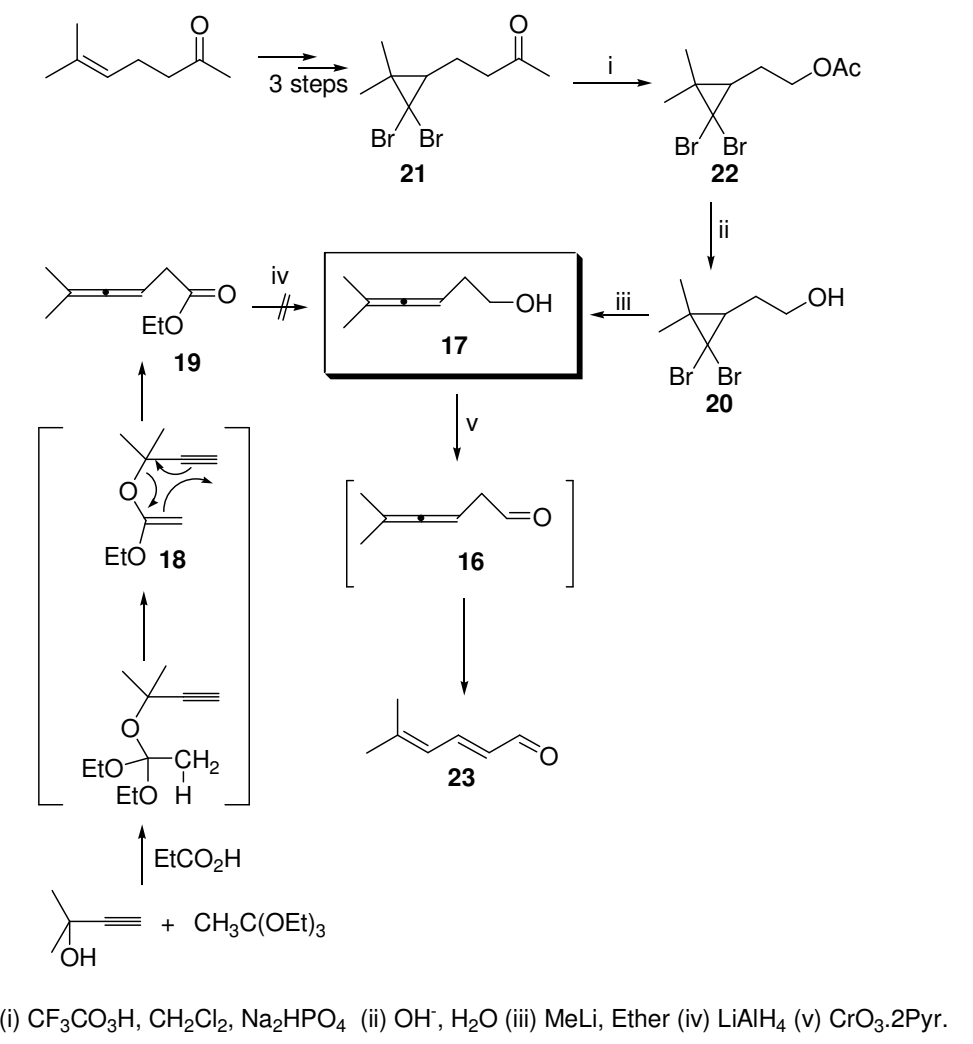

Scheme 4

The 2,4-hexadienal 23 was characterized on the basis of spectroscopic data. The appearance of the carbonyl group absorption at $1680 \mathrm{~cm}^{-1}$ in the IR spectrum is characteristic of $\alpha$, $\beta$ unsaturated aldehydes. The ${ }^{1} \mathrm{H}$ NMR spectrum indicated the presence of three olefinic protons (contrary to one olefinic proton as it would be for compound 16), a multiplet at $6.0 \mathrm{ppm}$ due to the $\alpha \mathrm{H}$ and the $\gamma \mathrm{H}$, and a dublet dublets at $7.5 \mathrm{ppm}$ due to the $\beta \mathrm{H}$. The appearance of a dublet for the adehydic proton at $9.5 \mathrm{ppm}$ suggests the presence of one proton at the $\alpha$-carbon (contrary to two protons as it would be the case of the allenic aldehyde 16). The singlet at $1.9 \mathrm{ppm}$ is due to the gem-dimethyl protons. The UV spectrum showed an absorption maximum at $274.5 \mathrm{~nm}(\varepsilon$ $=17600$ ) which is expected for a dienal chromophore.

Dissatisfied with this isomerization of the anticipated aldehyde $\mathbf{1 6}$ to $\mathbf{2 3}$, we terminated efforts to prepare $\mathbf{1 6}$ as a key intermediate towards the targeted allenic ketones $\mathbf{4 a}$ and $\mathbf{4 b}$. Our second route towards the allenic ketone 4a is summarized in Scheme 5. In this strategy we aimed at the 1,3-dthiane derivative $\mathbf{2 4}$, which we anticipated would easily be converted to $\mathbf{4 a}$. 2Allyl-1,3-diathiane (25) was obtained in $90 \%$ yield from the lithium derivative of 1,3-dithiane (26) and allyl bromide. However, the conversion of 25 to 27 proved to be problematic, presumably because the intermediate, lithiated $\mathbf{2 5}$, could have reacted with the acetylenic proton of the propargylic bromide and thereby regenerating 25. To circumvent this problem, we decided to form the allene functionality prior to coupling with $\mathbf{2 5}$. We, thus, prepared the allenic 
bromopentadiene 29, albeit in very low yield, starting from the commercially available propargyl alcohol. The diol $\mathbf{2 8}$ was prepared by reacting acetone and the ethynyl Grignard reagent derived from propargyl alcohol. Treatment of 28 with $\mathrm{HCl} / \mathrm{CaCl}_{2}$ afforded 4-chloro-4methyl-2-pentyn-1-ol, which was converted, without isolation, to 4-methyl-2,3-pentadien-1-ol by reaction with $\mathrm{LiAlH}_{4}$. Treatment of the latter allenic pentadienol with $\mathrm{PBr}_{3}$ furnished the allenic bromopentadiene 29, which was coupled with 25 to furnish 24 in $58 \%$ yield. The allene 24 was characterized on the on the basis of spectral data. The presence of the allenic bond is shown by an infrared band at $1955 \mathrm{~cm}^{-1}$. The ${ }^{1} \mathrm{H}$ NMR spectrum is consistent with the structure. However the low yield of $\mathbf{2 9}$ coupled with the moderate yield of $\mathbf{2 4}$ left us with insufficient material for subsequent transformations. This was certainly not satisfactory, and we looked for alternative ways of synthesizing compound $\mathbf{4 a}$.

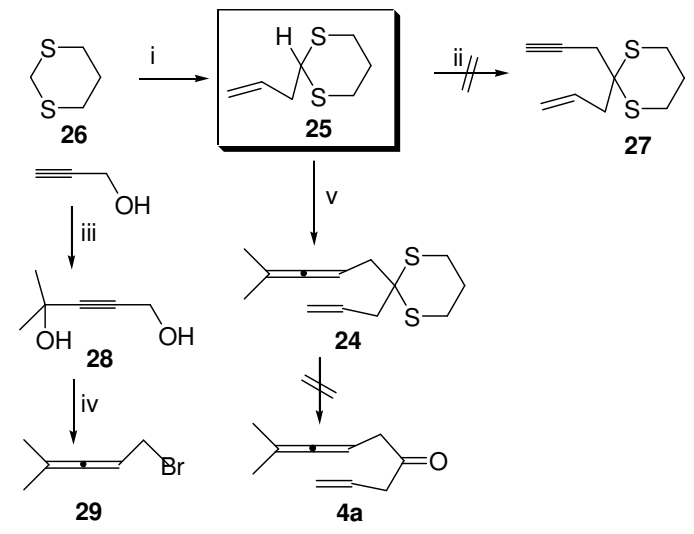

(i) (a) BuLi (b) allyl bromide (ii) (a) BuLi (b) propargyl bromide (iii) (a) EtMgBr (b)acetone (iv) (a) $\mathrm{HCl} / \mathrm{CaCl}_{2}$ (b) $\mathrm{LAH}$ (c) $\mathrm{PBr}_{3}$ (v) (a) BuLi (b) 29

Scheme 5

The fact that 2-(2,2-dibromo-3,3-dimethylcyclopropyl) ethanol (20) was obtained in 76\% overall yield from 6-methyl-5-hepten-2-one prompted us to revisit our first strategy (Scheme 4, vide supra) with some modifications in mind. Thus, in our third strategy, we planned to form the aldehyde functionality prior to the introduction of the allenic moiety. This strategy aimed at circumventing the isomerization that occurred for the allenic aldehyde 16. This route towards the allenic ketone $\mathbf{4 a}$ is depicted in Scheme 6 [steps (i)-(iii) are included for completeness as they have already been discussed in Scheme 4].

Swern [13] oxidation of alcohol 20 furnished 2-(2,2-dibromo-3,3-dimethylcyclopropyl) ethanal (30), which was transformed, without isolation, to 1-(2,2-dibromo-3,3dimethylcyclopropyl)-4-penten-2-ol (31) in 71\% overall yield from 20. Treatment of $\mathbf{3 1}$ with NO-bis-trimethylsilylacetamide in the presence of a catalytic amount of trimethylchlorosilane [14] gave the silyl ether $\mathbf{3 2}$ in $90 \%$ yield. The silyl ether was converted to the vinyl allene $\mathbf{3 3}(61 \%$ yield) by treatment of $\mathbf{3 2}$ with $\mathrm{MeLi}$ at $-5{ }^{\circ} \mathrm{C}$, and Jones oxidation of the allene gave the desired ketone 4a in $61 \%$ yield. Infrared absorption at 1965 and $1705 \mathrm{~cm}^{-1}$ are characteristic of the allenic linkage and isolated carbonyl group, respectively, and the NMR spectra fully confirm the structure of the desired allenic ketone $\mathbf{4 a}$. 


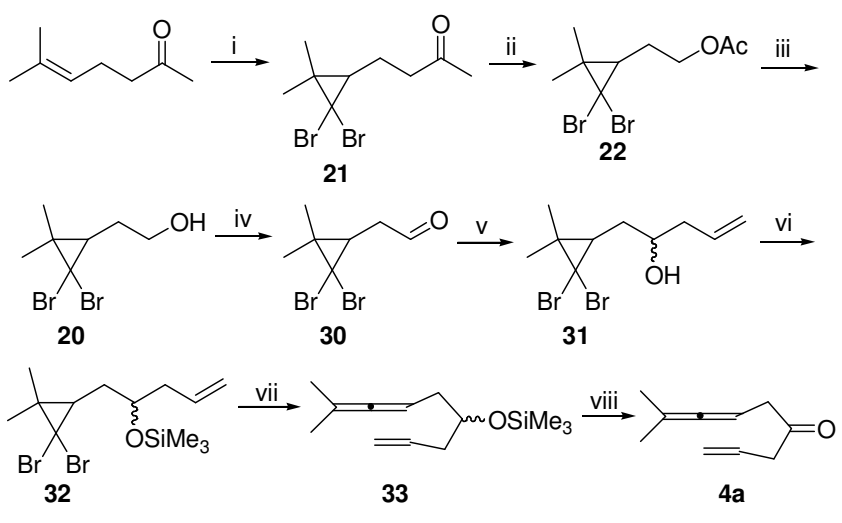

(i) (a) $\mathrm{HOCH}_{2} \mathrm{CH}_{2} \mathrm{OH} / \mathrm{H}^{+}$(b) $\mathrm{CBr}_{2}$ (c) $\mathrm{H}_{3} \mathrm{O}^{+}$(ii) $\mathrm{CF}_{3} \mathrm{CO}_{3} \mathrm{H}$ (iii) $15 \% \mathrm{NaOH}$ (iv) $\mathrm{DMSO}^{-}\left(\mathrm{COCl}_{2}\right.$ (v) allylzinc bromide (vi) $\mathrm{N}$-O-bis-trimethylsilylacetamide (vii) $\mathrm{MeLi}$ (viii) $\mathrm{CrO}_{3}$ (Jones)

Scheme 6

Although we are not fully satisfied with the length (large number of steps) and linearity of the strategy, we nevertheless have successfully prepared the desired ketone $4 \mathbf{a}$ in $21 \%$ overall yield from compound $\mathbf{2 1}$. It is, therefore, possible to prepare sufficient amounts of compound $\mathbf{4 a}$ by scaling up the synthesis or conducting repeated preparations. We also have prepared the thioketal-protected target ketone in the form of compound 24 (Scheme 5). It is, therefore, worthy revisiting this shorter and convergent route towards $\mathbf{4 a}$ with the purpose to improve the yield of the bromopentadiene $\mathbf{2 9}$ and, subsequently, that of compound 24. Furthermore, it may be desirable to design a shorter and convergent route to 8-Methylnonane-1,6,7-trien-5-one, a regioisomer of $\mathbf{4 a}$, using some of the compounds prepared in this work, for example, 4-methyl2,3-pentadien-1-ol, which was the precursor for the bromopentadiene 29 in Scheme 5.

\section{EXPERIMENTAL}

\section{General}

Reagents. Unless otherwise indicated all analytical grade reagents were used without further purification. Other grades were purified according to known procedures before use.

Instruments. Capillary gas-liquid chromatography (GLC) analyses were carried out on a Varian 3400 Gas Chromatograph using a supelcowax 10 wall-coated column of $30 \mathrm{~m}$ length and 0.25 $\mathrm{mm}$ internal diameter. Other analytical GLC were carried out on either a Hewlett Packard 5710a Gas Chromatograph using 3\% SP 2100 packed column of $2.5 \mathrm{~m}$ length and $2 \mathrm{~mm}$ internal diameter or on Chrompack CP 9001 Gas Chromatograph using 3\% OV-17 packed column of 2 $\mathrm{m} \times 1 / 4$ × $2 \mathrm{~mm}$ dimensions. Thin-layer chromatography (TLC) was carried out on aluminium plates pre-coated with silica gel $60 \mathrm{~F}_{254}$. The spots were visualized by illuminating with UV lump ( $254 \mathrm{~nm})$ or by using $p$-anisaldehyde spray reagent. Infrared (IR) spectra were recorded on either a Perkin-Elmer Infrared Spectrometer 1310 or a Magna-IR Spectrometer 550. Absorptions are indicated as $(\mathrm{s})=$ strong, $(\mathrm{m})=$ medium, and $(\mathrm{w})=$ weak. NMR Spectra: ${ }^{1} \mathrm{H}$ and ${ }^{13} \mathrm{C}$ NMR spectra were recorded on the following instruments: Jeol PMX60 $\mathrm{SI}$ NMR Spectrometer operating at $60 \mathrm{MHz}$, Varian Gemini-200 NMR spectrometer, varian XL-300 NMR Spectrometer, and dpx-300 NMR Spectrometer. Tetramethylsilane (TMS) was used as an 
internal standard. Ultraviolet (UV) spectra were recorded on a Shimadzu UV-VIS Recording Spectrophotometer UV-260. Melting points were taken on a Buchi melting point apparatus and are uncorrected.

1,3-Dithiane (26) was prepared from 1,3-propanethiol and formaldehyde dimethylacetal in the presence of catalytic amount of $\mathrm{BF}_{3} . \mathrm{OEt}_{2}$ according to literature, m.p. 51.5-52.5 ${ }^{\circ} \mathrm{C}$, (lit. [15] m.p. 53-54 $\left.{ }^{\circ} \mathrm{C}\right) .{ }^{1} \mathrm{H} \mathrm{NMR}\left(200 \mathrm{MHz}, \mathrm{CDCl}_{3}\right): \delta 2.10(\mathrm{~m}, 2 \mathrm{H}), 2.85(\mathrm{t}, J 6.6 \mathrm{~Hz}, 4 \mathrm{H}), 3.78(\mathrm{~s}, 2$ $\mathrm{H})$.

2-Allyl-1,3-dithiane (25). A solution of 1,3-dithiane $(6 \mathrm{~g}, 0.05 \mathrm{~mol})$ in THF $(150 \mathrm{~mL})$ was cooled to $-40{ }^{\circ} \mathrm{C}$ and kept under a $\mathrm{N}_{2}$ atmosphere. To the dithiane-THF solution was dropwise added $n$-BuLi $(33 \mathrm{~mL}, 0.0525 \mathrm{~mol})$. The resulting solution was stirred at -25 to $-15{ }^{\circ} \mathrm{C}$ for $4 \mathrm{~h}$ and the cooled to $-75^{\circ} \mathrm{C}$ followed by addition of allyl bromide $(6.05 \mathrm{~g}, 0.05 \mathrm{~mol})$. The resulting mixture was stirred overnight when the temperature gradually rose from $-75{ }^{\circ} \mathrm{C}$ to $0{ }^{\circ} \mathrm{C}$. The reaction was quenched by addition of $50 \mathrm{~mL}$ of water. The aqueous phase was extracted with ( 5 x $30 \mathrm{~mL})$ and the combined organic solution dried $\left(\mathrm{K}_{2} \mathrm{CO}_{3}-\mathrm{MgSO}_{4}\right)$. Evaporation of the solvent left an oil which was distilled under reduced pressure to give $7.215 \mathrm{~g}$ (90\%) of 25 [16], b.p. 102-104 ${ }^{\circ} \mathrm{C} / 10$ mmHg. IR (film): 3066 (m), 2892 (s), 1642 (m), 1414 (s), 991 (s), 910 (s), 769 (s) $\mathrm{cm}^{-1} .{ }^{1} \mathrm{H}$ NMR $\left(200 \mathrm{MHz}, \mathrm{CDCl}_{3}\right): \delta 1.85(\mathrm{~m}, 1 \mathrm{H}), 2.10(\mathrm{~m}, 1 \mathrm{H}), 2.50(\mathrm{t}, J 6.6 \mathrm{~Hz}, 2 \mathrm{H})$, 2.85 (m, 4 H), 4.10 (t, J 6.6 Hz, $1 \mathrm{H}), 5.10$ (m, 2 H), 5.85 (m, $1 \mathrm{H})$.

4-Methyl-2-pentyn-1,4-diol (28). To ethylmagnesium bromide, prepared in the usual way from ethyl bromide $(87.18 \mathrm{~g}, 0.8 \mathrm{~mol})$ and magnesium $(19.44 \mathrm{~g}, 0.8 \mathrm{~mol})$ in ether $(600 \mathrm{~mL})$ and cooled to $0{ }^{\circ} \mathrm{C}$, was added a solution of the propargyl alcohol $(22 \mathrm{~g}, 0.39 \mathrm{~mol})$ in THF (100 $\mathrm{mL}$ ). The resulting mixture was stirred at room temperature for $3 \mathrm{~h}$ and then a solution of acetone $(23 \mathrm{~g}, 0.4 \mathrm{~mol})$ in THF $(100 \mathrm{~mL})$ was added. Stirring at room temperature was continued overnight and then the reaction was quenched with saturated aqueous $\mathrm{NH}_{4} \mathrm{Cl}$ solution. The organic phase was separated and the aqueous phase was subjected to continuous extraction with ether. The combined organic solution was dried $\left(\mathrm{MgSO}_{4}\right)$. After evaporation of the solvent a viscous oil was left. Distillation under reduced pressure gave $32.20 \mathrm{~g} \mathrm{(72 \% )}$ of the diol 28, b.p. $80{ }^{\circ} \mathrm{C} / 0.05 \mathrm{mmHg}$, (lit. [17] b.p. $91{ }^{\circ} \mathrm{C} / 1 \mathrm{mmHg}$ ). IR (film): 3300 (s), 2960 (s), 1350 (s), 1225 (s), 1150 (s), 1050 (s), $\mathrm{cm}^{-1} .{ }^{1} \mathrm{H}$ NMR (200 $\left.\mathrm{MHz}, \mathrm{CDCl}_{3}\right)$ : $\delta 1.50(\mathrm{~s}, 6 \mathrm{H}), 4.05(\mathrm{~s}, 2 \mathrm{H}), 4.27(\mathrm{~s}, 2 \mathrm{H}) .{ }^{13} \mathrm{C} \mathrm{NMR}\left(50 \mathrm{MHz}, \mathrm{CDCl}_{3}\right): \delta 32.62\left(2 \mathrm{CH}_{3}\right), 51.74$ (C-O), 66.08 (C-O), 81.17 (acetylenic C), 91.03 (acetylenic C).

4-Chloro-4-methyl-2-pentyn-1-ol. To a mixture of $37 \% \mathrm{HCl}(16 \mathrm{~mL}, 0.177 \mathrm{~mol})$ and $\mathrm{CaCl}_{2}(16$ $\mathrm{g}, 0.144 \mathrm{~mol})$ the diol 28 (12 g, $0.104 \mathrm{~mol})$ was added and the resulting mixture was shaken with cooling (ice-water bath) for $5 \mathrm{~min}$. The two layers were separated and the aqueous layer was extracted several times with ether. The combined organic solution was dried $\left(\mathrm{K}_{2} \mathrm{CO}_{3}\right.$ $\mathrm{MgSO}_{4}$ ). Filtration followed by evaporation of the solvent gave the crude 4-chloro-4-methyl-2pentyn-1-ol [18] as a dark brown oil. A small quantity was purified by flash chromatography (silica, 1:2 EtOAc/pet. ether) to give a pure sample of the chloropentynol for spectroscopic analyses. IR (film): 3300 (s), 2920 (s), 1610 (m), 1430 (s), 1360 (s), 900 (s), $\mathrm{cm}^{-1}$. ${ }^{1} \mathrm{H}$ NMR (200 $\left.\mathrm{MHz}, \mathrm{CDCl}_{3}\right): \delta 1.81(\mathrm{~s}, 6 \mathrm{H}), 2.60(\mathrm{~s}, 1 \mathrm{H}), 4.30(\mathrm{~s}, 2 \mathrm{H}) .{ }^{13} \mathrm{C} \mathrm{NMR}\left(50 \mathrm{MHz}, \mathrm{CDCl}_{3}\right): \delta 36.04$ $\left(2 \mathrm{CH}_{3}\right), 52.00(\mathrm{C}-\mathrm{O}), 58.75(\mathrm{C}-\mathrm{Cl}), 83.00$ (acetylenic $\mathrm{C}$ ), 89.00 (acetylenic $\mathrm{C}$ ).

4-Methyl-2,3-pentadien-1-ol. The crude 4-chloro-4-methyl-2-pentyn-1-ol was dissolved in dry ether $(50 \mathrm{~mL})$ and added dropwise to a suspension of $\mathrm{LiAlH}_{4}(5.6 \mathrm{~g}, 0.15 \mathrm{~mol})$ [19] in ether $(200 \mathrm{~mL}) \mathrm{kept}$ at room temperature. After complete addition of the chlorohydrin-ether solution, the mixture was refluxed for $45 \mathrm{~min}$, cooled and water added dropwise to quench the reaction. 
The reaction mixture was worked up as usual and the product purified by flash chromatography (silca, 1:2 $\mathrm{Et}_{2} \mathrm{O} /$ pentane) to give $4.945 \mathrm{~g},(53 \%)$ of 4-methyl-2,3-pentadien-1-ol [20]. IR (film): 3300 (s), 2900 (s), 1955 (m), 1430 (s), 1400 (s), 1000 (s), cm ${ }^{-1} \cdot{ }^{1} \mathrm{H}$ NMR (200 MHz, CDCl ${ }_{3}$ ): $\delta 1.70(\mathrm{~d}, J 1 \mathrm{~Hz}, 3 \mathrm{H}), 1.71(\mathrm{~d}, J 1 \mathrm{~Hz}, 3 \mathrm{H}), 2.19(\mathrm{~s}, 1 \mathrm{H}), 4.04(\mathrm{~d}, J 4.8 \mathrm{~Hz}, 2 \mathrm{H}), 5.15(\mathrm{~m}, 1$ $\mathrm{H})$.

1-Bromo-4-methylpenta-2,3-diene (29). To a cooled mixture of 4-methyl-2,3-pentadien-1-ol $(3.3 \mathrm{~g}, 0.034 \mathrm{~mol})$ in pet. ether $(15 \mathrm{~mL})$ and pyridine $(3.4 \mathrm{~mL})$ was dropwise added a solution of $\mathrm{PBr}_{3}(5.1 \mathrm{~g}, 0.018 \mathrm{~mol})$ in pet. ether $(12 \mathrm{~mL})$. The reaction progress was monitored by GLC and found to be complete within 30 min since complete addition of $\mathrm{PBr}_{3}$. The mixture was poured into ice water and the organic phase separated from the aqueous phase. The aqueous phase was extracted with ether and the combined organic solution was dried $\left(\mathrm{MgSO}_{4}\right)$. Filtration and removal of the solvent left the crude product as a liquid. Distillation under reduced pressure gave only $1.1 \mathrm{~g}(20 \%)$ of the bromopentadiene 29 , bp. $40{ }^{\circ} \mathrm{C} / 10 \mathrm{mmHg}$. A substantial degree of polymerization occurred. ${ }^{1} \mathrm{H} \mathrm{NMR}\left(200 \mathrm{MHz}, \mathrm{CDCl}_{3}\right): \delta 1.70(\mathrm{~s}, 3 \mathrm{H}), 1.71(\mathrm{~s}, 3 \mathrm{H}), 3.90(\mathrm{~d}, J 9$ $\mathrm{Hz}, 2 \mathrm{H}), 5.25$ (m, $1 \mathrm{H})$.

2-Allyl-2-(4-methyl-2,3-pentadienyl)-1,3-dithiane (24). To a solution of 2-allyl-1,3-dithiane (25) $(0.8 \mathrm{~g}, 5 \mathrm{mmol})$ in dry THF $(15 \mathrm{~mL})$, cooled to $-40{ }^{\circ} \mathrm{C}$ and kept under a $\mathrm{N}_{2}$ atmosphere, was dropwise added $n$-BuLi $(5.25 \mathrm{mmol})$ [16]. The resulting mixture was stirred for $3 \mathrm{~h}$ at -25 to -15 ${ }^{\circ} \mathrm{C}$ and then cooled to $-75{ }^{\circ} \mathrm{C}$ followed by addition of the bromopentadiene $29(0.8 \mathrm{~g}, 5 \mathrm{mmol})$. The resulting mixture was stirred overnight when the temperature rose from -75 to $0{ }^{\circ} \mathrm{C}$. The usual workup followed by flash chromatography (silica, pet. ether/EtOAc 9:1) gave $0.7 \mathrm{~g} \mathrm{(58 \% )}$ of 24 as a viscous oil. IR (film): 2895 (s), 1955 (m), $1625(\mathrm{~m}), 1420(\mathrm{~s}), 985$ (s), $910 \mathrm{~cm}^{-1} .{ }^{1} \mathrm{H}$ NMR $\left(200 \mathrm{MHz}, \mathrm{CDCl}_{3}\right): \delta 1.68(\mathrm{~s}, 3 \mathrm{H}), 1.69(\mathrm{~s}, 3 \mathrm{H}), 1.95(\mathrm{~m}, 2 \mathrm{H}), 2.58(\mathrm{~d}, J 9 \mathrm{~Hz}, 2 \mathrm{H})$, $2.65(\mathrm{~d}, J 9 \mathrm{~Hz}, 2 \mathrm{H}), 2.86(\mathrm{~m}, 4 \mathrm{H}), 5.00(\mathrm{~m}, 1 \mathrm{H}), 5.10(\mathrm{~m}, 2 \mathrm{H}), 5.85(\mathrm{~m}, 1 \mathrm{H})$.

1-Acetoxy-2-(2,2-dibromo-3,3-dimethylcyclopropyl)ethane (22) was prepared in 95\% yield by oxidation of 4-(2,2-dibromo-3,3-dimethylcyclopropyl)butan-2-one with peroxytrifluoroacetic acid [21]. IR (film): 2900 (s), 2800 (s), 1739 (s), 1455 (s), 1360 (s), 1230 (s) cm ${ }^{-1} .{ }^{1} \mathrm{H}$ NMR $\left(200 \mathrm{MHz}, \mathrm{CDCl}_{3}\right): \delta 1.18(\mathrm{~s}, 3 \mathrm{H}), 1.28(\mathrm{t}, J 6.6 \mathrm{~Hz}, 1 \mathrm{H}), 1.37(\mathrm{~s}, 3 \mathrm{H}), 1.75(\mathrm{~m}, 2 \mathrm{H}), 2.05(\mathrm{~s}$, $3 \mathrm{H}), 4.17$ (t, $J 6.6 \mathrm{~Hz}, 2 \mathrm{H})$.

2-(2,2-dibromo-3,3-dimethylcyclopropyl)ethanol (20) [22] was obtained in $92 \%$ yield by base catalyzed hydrolysis of the acetate 22. ${ }^{1} \mathrm{H}$ NMR $\left(200 \mathrm{MHz}, \mathrm{CDCl}_{3}\right): \delta 1.20(\mathrm{~s}, 3 \mathrm{H}), 1.26(\mathrm{t}, J$ $6.6 \mathrm{~Hz}, 1 \mathrm{H}), 1.30(\mathrm{~s}, 3 \mathrm{H}), 1.70(\mathrm{~m}, 2 \mathrm{H}), 2.10(\mathrm{br} \mathrm{s}, 1 \mathrm{H}), 3.75(\mathrm{t}, J 6.6 \mathrm{~Hz}, 2 \mathrm{H})$.

5-Methyl-3,4-hexadien-1-ol (17). A $250 \mathrm{~mL}$ two necked flask provided with a condenser and a septum, kept under $\mathrm{N}_{2}$ stream, was charged with a solution of alcohol 20 (13.6 g, $\left.50 \mathrm{mmol}\right)$ in dry ether $(100 \mathrm{~mL})$ and cooled in an ice-water bath. An ethereal solution of $1.5 \mathrm{M} \mathrm{MeLi}(83 \mathrm{~mL}$, $125 \mathrm{mmol}$ ) was added dropwise with stirring. The reaction mixture was further stirred for 15 min and then poured into cold saturated $\mathrm{NH}_{4} \mathrm{Cl}$ solution. The ether layer was separated and the aqueous layer extracted with ether. The combined ethereal solution was dried $\left(\mathrm{Na}_{2} \mathrm{SO}_{4}\right)$ and the solvent distilled of yielding a liquid $(5.3 \mathrm{~g}, 95 \%)$ which was pure enough for spectroscopic characterization. B.p. $74-76{ }^{\circ} \mathrm{C} / 20 \mathrm{mmHg}$ (lit. [23] $75{ }^{\circ} \mathrm{C} / 20 \mathrm{mmHg}$ ). IR (film): selected bands at 3320 (s) $\mathrm{OH}, 2900$ (s) aliphatic $\mathrm{CH}, 1960$ (w) allenic $\mathrm{C}=\mathrm{C}=\mathrm{C}$ str., $\mathrm{cm}^{-1} .{ }^{1} \mathrm{H}$ NMR (200 MHz, $\left.\mathrm{CDCl}_{3}\right): \delta 1.70(\mathrm{~d}, 6 \mathrm{H}), 2.20(\mathrm{q}, 2 \mathrm{H}), 2.40($ broad s, $1 \mathrm{H}), 3.70(\mathrm{t}, 2 \mathrm{H}), 5.0(\mathrm{~m}, 1 \mathrm{H})$. 
5-Methyl-2,4-hexadienal (23). Chromium trioxide ( $4 \mathrm{~g}, 40 \mathrm{mmol}$ ) was added portion-wise to a stirred solution of dry pyridine $(6.3 \mathrm{~g}, 80 \mathrm{mmol})$ in $\mathrm{CH}_{2} \mathrm{Cl}_{2}(75 \mathrm{~mL})$ at room temperature (with occasional cooling in a cold water bath). After the addition of $\mathrm{CrO}_{3}$ was complete, the mixture was further stirred for $15 \mathrm{~min}$ and then the allenic alcohol $17(0.56 \mathrm{~g}, 5 \mathrm{mmol})$ in dry $\mathrm{CH}_{2} \mathrm{Cl}_{2}$ $(2.5 \mathrm{~mL})$ was added dropwise with stirring. The mixture was stirred for $30 \mathrm{~min}$ and then the $\mathrm{CH}_{2} \mathrm{Cl}_{2}$ solution was decanted from the black-tarry solid, the solid was washed several times with ether, the organic solutions combined and washed thrice with $10 \%$ aqueous $\mathrm{NaOH}$, once with $5 \%$ aqueous $\mathrm{HCl}, 5 \%$ aqueous $\mathrm{NaHCO}_{3}$ and saturated aqueous $\mathrm{NaCl}$ solution. After drying $\left(\mathrm{MgSO}_{4}\right)$ and removal of the solvents, GLC analysis of the residue indicated presence of substantial amount of pyridine, which was removed by column chromatography on silica gel $\left(\mathrm{CH}_{2} \mathrm{Cl}_{2}\right)$ yielding 23 as a yellow oil $(0.36 \mathrm{~g}, 65 \%)$. IR (film): selected bands at $3310(\mathrm{w}), 2900$ (s) aliphatic $\mathrm{CH}, 1680$ (s) $\alpha, \beta$-unsaturated $\mathrm{C}=\mathrm{O}, \mathrm{cm}^{-1} .{ }^{1} \mathrm{H}$ NMR $\left(200 \mathrm{MHz}, \mathrm{CDCl}_{3}\right): \delta 1.90$ (s, 6 $\mathrm{H}), 6.00(\mathrm{~m}, 2 \mathrm{H}, \alpha \mathrm{H}+\gamma \mathrm{H}), 7.50(\mathrm{dd}, 1 \mathrm{H}, \beta \mathrm{H}), 9.50(\mathrm{~d}, 1 \mathrm{H}, \mathrm{CH}=\mathrm{O})$. UV (hexane): $\lambda_{\max } 274.5$ $\mathrm{nm}(\varepsilon=17600)$.

Ethyl 5-methyl-3,4-hexadienoate (19). The $\beta$-allenic ester was prepared according to literature [24]. IR (film): selected bands at 2920 (s) aliphatic $\mathrm{CH}, 1970$ (w) allenic $\mathrm{C}=\mathrm{C}=\mathrm{C}$ str., 1735 (s) $\mathrm{C}=\mathrm{O}$ ester, $\mathrm{cm}^{-1} .{ }^{1} \mathrm{H}$ NMR $\left(200 \mathrm{MHz}, \mathrm{CDCl}_{3}\right): \delta 1.25(\mathrm{t}, 3 \mathrm{H}), 1.70(\mathrm{~d}, 6 \mathrm{H}), 3.0(\mathrm{~d}, 2 \mathrm{H}), 4.10$ $(\mathrm{q}, 2 \mathrm{H}), 5.05(\mathrm{~m}, 1 \mathrm{H})$.

1-(2,2-dibromo-3,3-dimethylcyclopropyl)-4-penten-2-ol (31). The cyclopropylethanol $202.72 \mathrm{~g}$, $10 \mathrm{mmol}$ ) was oxidized employing the Swern procedure [13]. After the usual workup and drying $\left(\mathrm{MgSO}_{4}\right)$ the solvent was removed and the crude cyclopropylethanal 30 was immediately dissolved in dry THF $(25 \mathrm{~mL})$. The resulting solution was cooled to $-20{ }^{\circ} \mathrm{C}$ and kept under a $\mathrm{N}_{2}$ atmosphere. To the cyclopropylethanal-THF solution, was added dropwise a solution of allylzinc bromide $(13 \mathrm{mmol})$ in THF $(20 \mathrm{~mL})$. The resulting mixture was kept at $-20{ }^{\circ} \mathrm{C}$ for 45 min and then the cooling bath was removed to allow the reaction to come to room temperature. The reaction was hydrolysed by $5 \% \mathrm{H}_{2} \mathrm{SO}_{4}(30 \mathrm{~mL})$ and extracted with ether $(3 \times 25 \mathrm{~mL})$. The combined organic phase was washed with $5 \% \mathrm{NaHCO}_{3}(3 \times 25 \mathrm{~mL})$, saturated $\mathrm{NaCl}(2 \times 25$ $\mathrm{mL})$ and dried $\left(\mathrm{MgSO}_{4}\right)$. The solvent was evaporated leaving viscous oil which was flash chromatographed (silica, pet. ether/EtOAc $65: 35)$ to give $2.2 \mathrm{~g}(71 \%)$ of the alcohol 31, as a mixture of diastereomers. IR (film): 3320 (s), 3020 (w), 2995 (s), 1625 (m), 1425 (s) cm ${ }^{-1}$. ${ }^{1} \mathrm{H}$ NMR (200 MHz, $\left.\mathrm{CDCl}_{3}\right): \delta 1.16(\mathrm{~s}, 3 \mathrm{H}), 1.25(\mathrm{~m}, 1 \mathrm{H}), 1.40(\mathrm{~s}, 3 \mathrm{H}), 1.35-1-70(\mathrm{~m}, 2 \mathrm{H}), 2.00$ (s, $1 \mathrm{H}), 2.10-2.45(\mathrm{~m}, 2 \mathrm{H}), 3.80(\mathrm{~m}, 1 \mathrm{H}), 5.20(\mathrm{~m}, 2 \mathrm{H}), 5.85(\mathrm{~m}, 1 \mathrm{H})$.

1-(2,2-dibromo-3,3-dimethylcyclopropyl)-2-trimethylsilyloxy-4-pentene (32). To the alcohol 31 $(5.35 \mathrm{~g}, 0.017 \mathrm{~mol})$, kept under a $\mathrm{N}_{2}$ atmosphere, was added $\mathrm{N}-\mathrm{O}$-bis-trimethylsilylacetamide $(1.74 \mathrm{~g}, 0.0086 \mathrm{~mol})$ followed by a catalytic amount of trimethylchlorosilane. The reaction was complete in an instant. A few drops of triethylamine were added to neutralize the small amount of $\mathrm{HCl}$ formed. The reaction mixture was extracted with ether, the extract washed with water and dried $\left(\mathrm{K}_{2} \mathrm{CO}_{3}-\mathrm{MgSO}_{4}\right)$. Filtration followed by evaporation of the solvent left oil which was purified by flash chromatography (silca, pet. ether/EtOAc 65:35) to afford the $5.9 \mathrm{~g}(90 \%)$ of the silyl ether 32. IR (film): 3020 (w), 2900 (s), 1630 (m), 1430 (s), 1360 (s), 1245 (s), 1085 (s), $830(\mathrm{~s}), 750(\mathrm{~s}) \mathrm{cm}^{-1} .{ }^{1} \mathrm{H}$ NMR $\left(200 \mathrm{MHz}, \mathrm{CDCl}_{3}\right): \delta 0.15(\mathrm{~m}, 9 \mathrm{H}), 1.18(\mathrm{~s}, 3 \mathrm{H}), 1.40(\mathrm{~s}, 3 \mathrm{H})$, 1.52-1.75 (m, $3 \mathrm{H}), 2.27(\mathrm{~m}, 2 \mathrm{H}), 3.85(\mathrm{~m}, 1 \mathrm{H}), 5.10(\mathrm{~m}, 2 \mathrm{H}), 5.80(\mathrm{~m}, 1 \mathrm{H})$.

8-Methyl-4-trimethylsilyloxynona-1,6,7-triene (33). The gem-dibromocyclopropane 32 (4.5 g, $0.012 \mathrm{~mol})$, in dry ether $(75 \mathrm{~mL})$, was cooled to $-5^{\circ} \mathrm{C}$. An ethereal solution of $1.6 \mathrm{M} \mathrm{MeLi} \mathrm{(10.9}$ $\mathrm{mL}, 0.0175 \mathrm{~mol}$ ) was added dropwise with stirring. The resulting mixture was further stirred for $15 \mathrm{~min}$ and then quenched by dropwise addition of water $(25 \mathrm{~mL})$. The organic phase was 
extracted with ether $(3 \times 35 \mathrm{~mL})$ and the combined organic extract dried $\left(\mathrm{MgSO}_{4}\right)$. Evaporation of the solvent left an oil, which was purified by distillation to give $1.6 \mathrm{~g}(61 \%)$ of the ene-allene 33, b.p. $48-50{ }^{\circ} \mathrm{C} / 0.1 \mathrm{mmHg}$. IR (film): 3025 (w), 2910 (s), 1965 (m), 1630 (m), 1430 (s), 1355 (s), 1250 (s), 1085 (s), 840 (s), 750 (s) $\mathrm{cm}^{-1} .{ }^{1} \mathrm{H}$ NMR (200 MHz, $\left.\mathrm{CDCl}_{3}\right): \delta 0.13$ (s, $\left.9 \mathrm{H}\right), 1.69$ $(\mathrm{s}, 3 \mathrm{H}), 1.70(\mathrm{~s}, 3 \mathrm{H}), 2.15(\mathrm{~m}, 2 \mathrm{H}), 2.25(\mathrm{~m}, 2 \mathrm{H}), 3.73(\mathrm{~m}, 1 \mathrm{H}), 4.94(\mathrm{~m}, 1 \mathrm{H}), 5.05(\mathrm{~m}, 2 \mathrm{H})$, $5.85(\mathrm{~m}, 1 \mathrm{H})$.

8-methylnonane-1,6,7-trien-4-one (4a). To a solution of the allene $33(2.8 \mathrm{~g}, 12.5 \mathrm{mmol})$ in acetone $(40 \mathrm{~mL})$, cooled to $-20^{\circ} \mathrm{C}$, was dropwise added Jones reagent $(6.25 \mathrm{~mL}, 15.5 \mathrm{mmol})$. The resulting mixture was kept at $-20{ }^{\circ} \mathrm{C}$ for $15 \mathrm{~min}$ and then allowed to come to room temperature $(2 \mathrm{~h})$. The organic phase was separated and the aqueous phase extracted with ether ( $3 \times 35 \mathrm{~mL}$ ). The combined organic phase was washed as follows: $2 \times 35 \mathrm{~mL}$ brine, $2 \times 35 \mathrm{~mL}$ $5 \%$ aq. $\mathrm{NaHCO}_{3}, 40 \mathrm{~mL}$ water and dried $\left(\mathrm{MgSO}_{4}\right)$. Removal of the solvent left a yellowish oil which was distilled to give $1.14 \mathrm{~g}(61 \%)$ of ketone 4a, b.p. $54{ }^{\circ} \mathrm{C} / 0.05 \mathrm{mmHg}$. IR (film): 3030 (w), 2900 (s), 1965 (s), 1705 (s), 1635 (m), 1420 (s), 1390 (s), 1320 (s), 1080 (s), 990 (s), 915 (s) $\mathrm{cm}^{-1} .{ }^{1} \mathrm{H} \mathrm{NMR}\left(200 \mathrm{MHz}, \mathrm{CDCl}_{3}\right): \delta 1.66(\mathrm{~s}, 3 \mathrm{H}), 1.67(\mathrm{~s}, 3 \mathrm{H}), 3.05(\mathrm{~d}, J 7 \mathrm{~Hz}, 2 \mathrm{H}), 3.22$ $(\mathrm{d}, J 7 \mathrm{~Hz}, 2 \mathrm{H}), 5.05-5.20(\mathrm{~m}, 3 \mathrm{H}), 5.90(\mathrm{~m}, 1 \mathrm{H}) .{ }^{13} \mathrm{C} \mathrm{NMR}\left(50 \mathrm{MHz}, \mathrm{CDCl}_{3}\right): \delta 21.84,44.39$, $47.99,82.55,96.78,119.12,130.79,202.78,205.88$.

\section{ACKNOWLEDGEMENTS}

The Norwegian Agency to International Development (NORAD) is greatly acknowledged for fully financing this research. The Chemistry Department, University of Oslo is greatly acknowledged for availing laboratory facilities for this research. The author would like also to thank his colleagues in the Chemistry Department, University of Dar es Salaam for their valuable inputs during the preparation of this paper.

\section{REFERENCES}

1. For reviews on allene chemistry, see (a) Schuster, H.F.; Coppola, G.M. Allenes in Organic Synthesis, Wiley-Interscience: New York; 1984, p 358; (b) Pasto, D.J. Tetrahedron 1984, 40, 2805; (c) Smadja, W. Chem. Rev. 1983, 83, 263; Munson, J.W. in The Chemistry of Ketenes, Allenes and Related Compounds, Part 1; Patai, S. (Ed.); Wiley-Interscience: New York, 1980; p 165.

2. Burton, B.S.; von Pechmann, H. Chem. Ber. 1887, 20, 145.

3. Jones, E.R.H.; Mansfield, G.H.; Whiting, M.L.J. J. Chem. Soc. 1954, 3208.

4. Landor, P. in The Chemistry of Allenes, Vol. 1; Landor, S.R. (Ed.); Academic Press: London; 1982; pp 21-233.

5. Landor, S.R.; Hopf, H.; Jacobs, T.L. in The Chemistry of Allenes, Vol. 2, Landor, S.R. (Ed.); Academic Press: London; 1982; pp 237-575.

6. Claeson, A.; Olsson, L.-I. in The Chemistry of Allenes, Vol. 3, Landor, S.R. (Ed.), Academic Press: London; 1982; pp 735-767.

7. Brusoe, A.J.; Alexanian, E.J. Angew. Chem. Int. Ed. 2011, 50, 6596.

8. Fernando L.; José, L.M. Beilstein J. Org. Chem. 2011, 7, 1075.

9. Skattebøl, L.; Stenstrøm, Y.; Uggerud, E. Acta Chem. Scand. B 1986, 40, 291; Skattebøl, L.; Solomon, S. J. Am. Chem. Soc. 1965, 87, 4506.

10. Hiroi, K., Watanabe, T. and Tsukui, A. Chem. Pharm. Bull. 2000, 48, 405. 
Synthesis of 8-methylnonane-1,6,7-trien-4-one and related allenes as synthetic precursors 113

11. Stenstrøm, Y. Stenstrøm, Y.; Rømming, C.; Skattebøl, L. Acta Chem. Scand. 1997, 51, 1134.

12. Nazarov, I.N..; Makin, S.M.; Kruptsov, B.K.; Mironov, V.A. J. Gen. Chem. USSR 1957, 27, 111.

13. Omura, K.; Swern, D. Tetrahedron 1978, 34, 1651; Mancuso, A.J.; Huang, S.-L.; Swern, D. J. Org. Chem. 1978, 43, 2480.

14. Cooper, B.E. Chem. Industry 1978, 794.

15. Corey, E.J.; Seebach, D. Org. Synth. 1970, 50, 72; Seebach, D.; Jones, N.R.; Corey, E.J. J. Org. Chem. 1968, 33, 300.

16. Seebach, D.; Beck, A.K. Org. Synth. 1971, 51, 76; Seebach, D.; Corey, E.J. J. Org. Chem. 1975, 40, 231; Seebach, D. Synthesis 1969, 17.

17. Vlasov, V.M.; Vasil'eva, A.A.; Semenova, E.F. Chem. Abstr. 1966, 56, 8744.

18. Brel, V.K.; Dogadina, A.V.; Zakharov, V.I.; Ionin, B.I.; Petrov, A.A. Chem. Abstr. 1980, 93, $186479 \mathrm{~g}$.

19. Bailey, W.J.; Pfeifer, C.R. J. Org. Chem. 1955, 20, 1337; Landor, P.D.; Landor, S.R.; Pepper, E.S. J. Chem. Soc. (C) 1967, 185.

20. Maurin, R.; Bertrand, M. Bull. Soc. Chim. Fr. 1972, 6, 2349.

21. Emmons, W.D.; Lucas, G.B. J. Am. Chem. Soc. 1955, 77, 2287.

22. Tokuyama Soda Co. Ltd Jpn Chem. Abstr. 1983, 104, 564r.

23. Olsson, L.; Claesson, A.; Bogentoft, C. Acta Chem. Scand. B 1974, 28, 765.

24. Crandall, J.K.; Tindell, G.L. J. Chem. Soc. D: Chem. Comm. 1970, 21, 1411. 